\title{
Optimasi Zeolit Alam Lampung (ZAL) Sebagai Penstabil Sediaan Antibakteri Esktrak Buah Mengkudu (Morinda citrifolia L.)
}

\section{Optimization of ZAL as a Stabilizer For The Antibacterial Preparation of Noni Fruit Extract (Morinda citrifolia L.)}

\author{
Laila Susanti ${ }^{\star}$, Lilik Koernia Wahidah, Pratika Viogenta \\ Farmasi-Universitas Tulang Bawang \\ Email : lailasusanti80@gmail.com
}

${ }^{*}$ Correspondent Author

\begin{abstract}
Noni fruit extract has been widely known as an antibacterial, but plant extracts are easily degraded by light, $\mathrm{pH}$ and temperature, thus reducing the antibacterial activity, zeolite is added to maintain the stability of the noni extract. This study uses an experimental method that is by comparing the inhibition zones that occur between noni fruit extract and noni + ZAL fruit extract and to test the stability of the preparation, the sample is heated at $40^{\circ} \mathrm{C}$ and then tested for antibacterial activity again. The statistical test results show the value of Asymp. Sig (0.003) $<p$ value (0.05) then $\mathrm{HO}$ was rejected so that the Mann Whitney test continued which showed that between samples KN, KP, KE and KE + ZAL showed significant differences. The KE sample has a smaller inhibition zone compared to $K E+Z A L$ which proves that ZAL can improve the performance of noni fruit extract in inhibiting S.aureus and P.aeruginosa bacteria. In the test of the stability of the preparation, the results showed that ZAL activation temperature of $100^{\circ} \mathrm{C}$ was able to improve the performance of noni fruit extract in inhibiting S.aureus bacteria by $84.59 \%$, but otherwise ZAL was unable to maintain the stability of Noni fruit extract against $P$.aeruginosa bacteria.
\end{abstract}

Key word : noni fruit, zeolite, S.aureus, P.aeruginosa

\begin{abstract}
Abstrak
Ekstrak tanaman buah mengkudu telah banyak dikenal sebagai antibakteri, namun ekstrak tanaman sangat mudah terdegradasi oleh cahaya, $\mathrm{pH}$ dan suhu sehingga menurunkan daya aktivitas antibakteri, untuk itu ditambahkan zeolit yang bertujuan untuk mempertahankan kestabilan dari sediaan ekstrak buah mengkudu. Penelitian ini mengunakan metode eksperimental yakni dengan membandingkan zona hambat yang terjadi antara ekstrak buah mengkudu saja dengan ekstrak buah mengkudu + ZAL dan untuk menguji kestabilan sediaan, sampel dipanaskan pada suhu $40^{\circ} \mathrm{C}$ dan kemudian diuji aktivitas antibakteri kembali. Hasil uji statistik menunjukan nilai Asymp. Sig $(0.003)$ < nilai $\mathrm{p}(0.05)$ maka HO ditolak sehingga dilanjutkan uji Mann Whitney yang menunjukkan bahwa antara sampel KN, KP, KE dan $\mathrm{KE}+\mathrm{ZAL}$ menunjukkan perbedaan yang bermakna. Sampel KE memiiki zona hambat lebih kecil dibandingkan dengan $\mathrm{KE}+\mathrm{ZAL}$ yang membuktikan bahwa ZAL mampu meningkatkan kinerja ekstrak buah mengkudu dalam menghambat bakteri S.aureus dan P.aeruginosa. Pada uji kestabilan sediaan, hasil menunjukkan bahwa ZAL suhu aktivasi $100^{\circ} \mathrm{C}$ mampu meningkatkan kinerja ekstrak buah mengkudu dalam mnghambat bakteri S.aureus sebesar $84,59 \%$, namun sebaliknya ZAL kurang mampu mempertahankan kestabilan ekstrak buah mengkudu terhadap bakteri $P$.aeruginosa.
\end{abstract}

Kata Kunci : Mengkudu, Zeolit, S.aureus, P.aeruginosa 


\section{PENDAHULUAN}

Provinsi Lampung merupakan daerah yang kaya akan kekayaan alam bahari, mineral, pertanian dan perkebunan. Salah satu kekayaan alam di Provinsi Lampung yang menjadi andalan adalah kekayaan alam tambang mineral, yakni zeolit. Zeolit dihasilkan dari proses hidrotermal pada batuan beku basa yang biasanya ditemukan pada celah-celah atau retakan batuan. Zeolit mempunyai struktur yang unik yakni memiliki kerangka tiga dimensi dengan porositas yang banyak mengandung molekul air, molekul logam dan sebagainya. Provinsi Lampung mempunyai cadangan lahan mineral zeolit kurang lebih sebesar 2.140.000 $\mathrm{m}^{3}$ dengan prediksi cadangan sebesar 8.000.000 $\mathrm{m}^{3}$ yang tersebar di beberapa wilayah di Provinsi Lampung [1].

Zeolit Alam Lampung (ZAL) memiliki jenis klinoptilolit dalam jumlah besar dan memiliki luas permukaan yang besar (70 $\mathrm{m}^{2}$ /gram) dalam bentuk H-Zeolit [2]. Klinoptilolit merupakan jenis zeolit yang mempunyai luas rongga cukup besar sehingga cocok digunakan sebagai disinfeksi bakteri. Keberadaan ZAL yang melimpah ini telah mendorong beberapa peneliti untuk mengaplikasikannya diantaranya sebagai adsorben gas $\mathrm{CO}_{2}$ dari biogas [3], adsorpsi fenol dengan fotokatalisis menggunakan $\mathrm{TiO}_{2}$ [4], dan sebagai penukar kation untuk penurunan kesadahan dalam air [5] serta menjaga stabilitas formula antibakteri [6].

Dari penjelasan yang telah dipaparkan di atas, maka peneliti ingin mengembangkan potensi ZAL yakni sebagai penstabil sediaan dari suatu ekstrak tanaman yang telah diketahui bersifat antibakteri. Beberapa ekstrak tanaman yang memberikan efek antibakteri yakni ekstrak kemangi terhadap Bacilus subtilis [7], ekstrak daun pepaya terhadap Staphylococcus aureus [8], ekstrak buah mengkudu terhadap bakteri Pseudomonas aeruginosa [9] dan Streptococcus mutans [10]. Potensi bahan alam yang berasal dari ekstrak tanaman umumnya mudah rusak akibat pengaruh pemanasan, $\mathrm{pH}$, kondisi asam atau basa serta cahaya sehingga dapat mendegradasi kemampuan antibakteri serta produk turunan yang dihasilkan tidak selalu aman bagi tubuh [11] [12].

Pada penelitian sebelumnya, uji daya hambat ekstrak buah mengkudu terhadap bakteri Streptococcus mutans memberikan nilai rerata zona hambat sebesar 20,41 mm, kontrol positif Clindamycin memberikan zona hambat $29,58 \mathrm{~mm}$. Peneliti lain juga melaporkan ekstrak buah mengkudu efektif menghambat pertumbuhan bakteri E.coli, E. Aerogenes, B.cereus, S.saprophyticus [13], dan fraksi kloroform buah mengkudu juga terbukti efektif menghambat perkembangan telur cacing H.contortus sebanyak $13,3 \%$ pada menit ke -5 dan menghambat $100 \%$ pada menit ke 120 [14]. Potensi ekstrak buah mengkudu sebagai antibakteri dilatar belakangi karena mengandung zat aktif flavonoid. Dengan membuat sediaan antibakteri dari ekstrak buah mengkudu kombinasi zeolit diharapkan dapat meningkatkan stabilitas formula dalam fungsinya menghambat bakteri. Aktivasi ZAL dilakukan pada suhu $100,200,300$ dan $400{ }^{\circ} \mathrm{C}$ untuk melihat kondisi optimum sebagai penstabil sediaan ekstrak buah mengkudu. Pemilihan suhu aktivasi ZAL didasarkan pada adanya molekul air dan oksida bebas seperti $\mathrm{CaO}, \mathrm{MgO}, \mathrm{Na}_{2} \mathrm{O}$ dan $\mathrm{K}_{2} \mathrm{O}$ yang menutupi pori atau situs aktif pada struktur kerangka ZAL, sehingga dengan membuat variasi suhu aktivasi molekul-molekul tersebut dapat dihilangkan dan kita dapat melihat unjuk kerja ZAL sebagai penstabil sediaan ekstrak antibakteri dari efek degradasi, pengaruh panas, $\mathrm{pH}$, cahaya dan sebagainya.

Pada Penelitian ini, uji antibakteri sediaan ekstrak mengkudu kombinasi ZAL dilakukan terhadap bakteri Staphylococcus aureus dan Pseudomonas aeruginosa. Pemilihan bakteri ini dilatar belakangi oleh sifat khas yang berbeda pada dinding sel bakteri. 
Kombinasi dua material ini yakni ZAL dan ekstrak buah mengkudu diharapkan sebagai terobosan baru sehingga dapat diaplikasikan dalam bidang farmasi dan kecantikan sebagai sediaan salep, krim atau sediaan lainya, sehingga dapat melahirkan produk unggulan yang bisa meningkatkan nilai ekonomi.

\section{METODE}

Penelitian ini merupakan jenis penelitian eksperimental. Penelitian dilakukan dari bulan Mei sampai Oktober 2018. Pada penelitian ini sumber daya alam daerah yakni Zeolit Alam Lampung (ZAL) memberikan suatu peluang pemanfaatan yang terbaru yaitu dapat menjadi penstabil sediaan antibakteri dari ekstrak buah mengkudu. Target utama dari penelitian ini adalah melihat optimasi dari ZAL melalui pengaruh suhu aktivasi dalam membantu kestabilan dari sediaan antibakteri ekstrak buah mengkudu. Data yang diperoleh dianalisis dengan SPSS, dan jika data yang didapatkan tidak homogen maka dilanjutkan dengan uji Kruskal Wallis.

Pembuatan esktrak buah mengkudu dilakukan dengan metode maserasi. Sampel buah mengkudu sebanyak 50 buah dikupas dan dipotong tipis-tipis, dikeringkan dengan cara diangin-anginkan selama \pm 3 hari dan tidak boleh terkena sinar matahari langsung. Setelah kering lalu diblender sampai terbentuk serat kasar. Serat kasar lalu ditimbang sebanyak $2 \mathrm{~kg}$ dimasukkan ke dalam wadah maserasi lalu ditambahkan etanol $70 \%$ hingga seluruh simplisia terendam, kemudian diaduk dan dilakukan pergantian pelarut hingga 3 kali. Semua hasil saringan dicampurkan dan dipekatkan dengan rotary evaporator pada suhu $70^{\circ} \mathrm{C}$ sampai didapat ekstrak kental. yang sudah homogen. Zeolit ini terlebih dahulu diidentifikasi dengan alat X-Ray Fluoresence (XRF) untuk melihat tingkat keamanan terhadap logam berat. Sampel zeolit diaktivasi dengan metode pemanasan pada suhu 100, 200, 300 dan $400{ }^{\circ} \mathrm{C}$ menggunakan furnace masingmasing selama 2 jam.

Pengujian aktivitas antibakteri ekstrak buah mengkudu tanpa zeolit dengan cara bakteri Staphylococcus aureus dan Pseudomonas aeruginosa yang disimpan di media agar diambil dari stok murni masing-masing bakteri ditanam dalam media pertumbuhan Nutrient Agar (NA) padat kemudian diinkubasi pada suhu 37 ${ }^{\circ} \mathrm{C}$ selama 24 jam dipanen dan dilarutkan dalam $\mathrm{NaCl}$ fisiologis sebanyak $10 \mathrm{~mL}$. Suspensi bakteri diukur kekeruhannya dengan Spektrofotometer pada panjang gelombang $600 \mathrm{~nm}$, lalu dibandingkan dengan 0,5 mcFarland, dan suspensi ini dihitung dengan $10^{8}$. Suspensi diencerkan dengan Nutrient Broth (NB) hingga mencapai $10^{6}$, dan bakteri uji siap digunakan, kemudian digoreskan merata pada masing-masing media NA yang steril sampai permukaannya tertutupi. Selanjutnya kertas cakram pertama dicelupkan ke dalam ekstrak buah mengkudu (KE), kertas cakram kedua dicelupkan dengan kontrol positif Gentamycin (KP) yang sudah dilarutkan dengan aquadest. Kertas cakram ketiga merupakan kontrol negatif (KN) yang dicelupkan dalam aquadest, selanjutnya kedua cawan petri diinkubasi pada suhu $37^{\circ} \mathrm{C}$ selama 24 jam. Zona hambat yang terbentuk disekitar kertas cakram diukur diameter vertikal dan diameter horizontal dengan jangka sorong.
Aktivasi Zeolit Alam Lampung (ZAL) didapatkan dari CV. Minatama Lampung yang dihasilkan dari pertambangan di wilayah provinsi Lampung dengan ukuran 
Perlakuan gabungan ekstrak buah mengkudu dengan zeolit yang telah diaktivasi, dilakukan dengan cara hasil ekstrak buah mengkudu yang telah dipekatkan selanjutnya digabungkan dengan ZAL yang telah diaktivasi pada suhu $100,200,300$ dan $400{ }^{\circ} \mathrm{C}$.

Metode gabungan dua material ini mengacu pada Bektas \& Kara (2004) yakni mencampurkan ZAL dan ekstrak buah mengkudu dengan perbandingan 1:1 yang di aduk dengan magnetic stirerr selama 24 jam dengan kecepatan 150 rpm pada suhu kamar.

Pengujian aktivitas antibakteri gabungan ekstrak buah mengkudu dengan zeolit yang telah diaktivasi dilakukan dengan cara seluruh sampel yang telah dicampurkan selanjutnya dilakukan uji aktivitas antibakteri dengan metode cakram Kirby-Bauer terhadap bakteri Staphylococcus aureus dan

Pseudomonas aeruginosa. Zona

hambat yang terbentuk disekitar kertas cakram diukur diameter vertikal dan diameter horizontal dengan jangka sorong.

Uji Efektivitas Zeolit Alam Lampung (ZAL) sebagai Penstabil Sediaan Antibakteri dilakukan untuk mengetahui unjuk kerja ZAL dalam membantu tingkat kestabilan suatu sediaan antibakteri setelah dilakukan pemanasan, karena seperti telah diketahui daya antibakteri ekstrak tanaman herbal akan menurun disebabkan oleh pemanasan. Pada tahap ini, seluruh sampel yakni kontrol negatif, kontrol positif gentamycin, ekstrak buah mengkudu tanpa zeolit, dan ekstrak buah mengkudu + zeolit (suhu aktivasi 100, 200, 300 dan $400^{\circ} \mathrm{C}$ ) dipanaskan pada suhu 40 ${ }^{\circ} \mathrm{C}$ selama 24 jam yang diaduk dengan magnetic stirrer. Kemudian seluruh sampel diuji aktivitas antibakteri menggunakan metode cakram KirbyBauer, zona hambat yang terbentuk disekitar kertas cakram diukur diameter vertikal dan diameter horizontal dengan jangka sorong.

\section{HASIL DAN PEMBAHASAN}

Hasil analisis berupa data zona hambat dari masing-masing sampel yakni KN (Kontrol Negatif), KP (Kontrol Positif/Salep Gentamycin), KE (Kontrol Esktrak Buah Mengkudu), $\mathrm{KE}+\mathrm{ZAL}_{100}, \mathrm{KE}+\mathrm{ZAL}_{200}$, $\mathrm{KE}+Z A L_{300}$, dan $\mathrm{KE}+Z A L_{400}$ (Ekstrak Buah Mengkudu+Zeolit suhu aktivasi 100, 200, 300 dan $400^{\circ} \mathrm{C}$ ) terhadap bakteri S.aureus dan P.aeruginosa baik sebelum pemanasan maupun sesudah pemanasan. Hasil data zona hambat disajikan pada Tabel dan Gambar di bawah ini.

Tabel 1. Nilai Rata-Rata Zona Hambat Sampel Terhadap S.aureus Sebelum Dan Sesudah Pemanasan

\begin{tabular}{ccc}
\hline Sampel & $\begin{array}{c}\text { Sebelum } \\
(\mathbf{m m})\end{array}$ & Sesudah (mm) \\
\hline KN & - & - \\
KP & 17,4 & 10,61 \\
KE & 20,68 & 15,00 \\
KE+ZAL 100 & 15,97 & 29,48 \\
KE+ZAL200 & 15,71 & 28,33 \\
KE+ZAL300 & 18,17 & 26,67 \\
KE+ZAL400 & 16,98 & 27,54
\end{tabular}
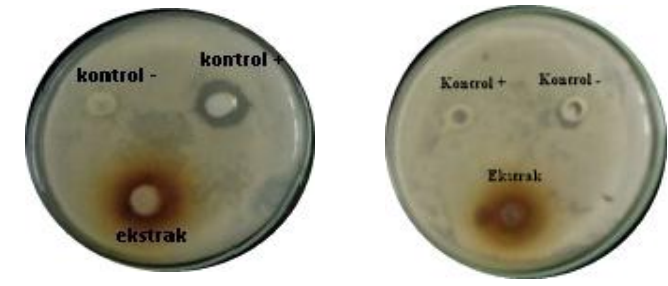

(A)
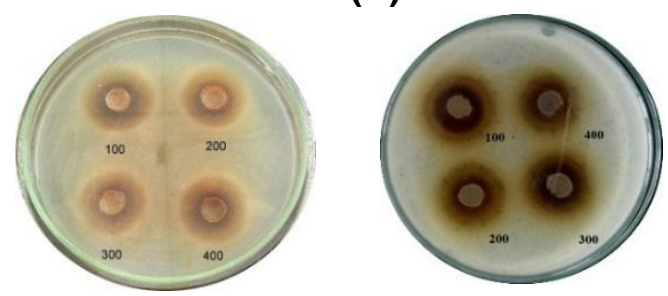

(B)

Gambar 1. Hasil uji aktivitas antibakteri KN, $\mathrm{KP}, \mathrm{KE}$ dan $\mathrm{KE}+\mathrm{Ze0} 100,200,300,400$ terhadap S.aureus (A) Sebelum Pemanasan (B) Sesudah Pemanasan 
Tabel 2. Nilai Rata-Rata Zona Hambat Sampel Terhadap P.aeruginosa Sebelum Dan Sesudah Pemanasan

\begin{tabular}{ccc}
\hline Sampel & $\begin{array}{c}\text { Sebelum } \\
(\mathbf{m m})\end{array}$ & $\begin{array}{c}\text { Sesudah } \\
(\mathbf{m m})\end{array}$ \\
\hline KN & - & - \\
KP & 12,65 & 10,84 \\
KE & 17,04 & 15,75 \\
KE+ZAL 100 & 30,89 & 26,54 \\
KE+ZAL 200 & 29,26 & 27,29 \\
KE+ZAL 300 & 30,25 & 27,56 \\
KE+ZAL400 & 31,39 & 27,33
\end{tabular}
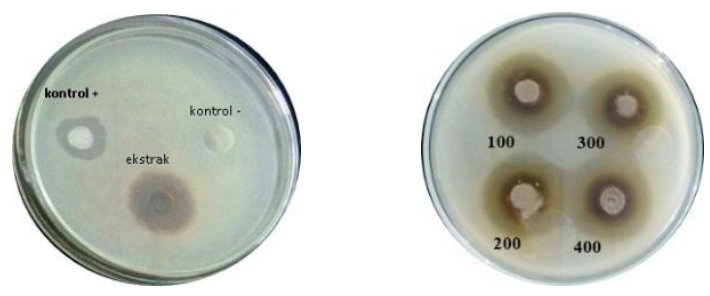

(A)
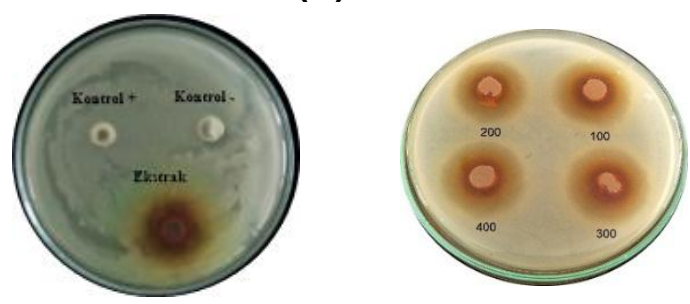

(B)

Gambar 2. Hasil uji aktivitas antibakteri KN, $\mathrm{KP}, \mathrm{KE}$, dan $\mathrm{KE}+\mathrm{Ze0} 100,200,300,400$ terhadap P.aeruginosa (A) Sebelum Pemanasan

Sesudah Pemanasan

Dari hasil pengamatan zona hambat Tabel 1 dan 2 sebelum pemanasan menunjukkan bahwa kecuali KN (Kontrol Negatif), seluruh sediaan sampel memberikan zona hambat terhadap S.aureus dan P.aeruginosa. Bahkan KE (Kontrol Esktrak) memberikan zona hambat lebih besar dibandingkan dengan KP (Kontrol Positif/Salep Gentamycin), namun tidak lebih besar dibandingkan dengan hasil zona hambat dari sampel $\mathrm{KE}+\mathrm{ZAL}$ untuk seluruh suhu aktivasi ZAL terutama terhadap bakteri $P$.aeruginosa. Hal ini menunjukkan adanya ZAL mampu meningkatkan kinerja ekstrak buah mengkudu dalam menghambat bakteri tersebut, karena seperti telah diketahui struktur kerangka zeolit memiliki pori-pori yang bersifat sebagai adsorben yang mampu merusak dinding sel bakteri [15].

Namun, terjadi fenomena yang berbeda setelah seluruh sampel dilakukan pemanasan, yakni pada Tabel 1 sampel $\mathrm{KP}$ dan KE mengalami penurunan zona hambat, sedangkan $\mathrm{KE}+\mathrm{ZAL}$ justru mengalami kenaikan zona hambat terhadap $S$. aureus. Sampel KP mengalami penurunan zona hambat sebesar $64 \%$ sedangkan sampel $\mathrm{KE}$ hanya mengalami penurunan zona hambat sebesar 37,86 \%. Hal ini menunjukkan bahwa zat sintetik kimiawi yang ada dalam salep Gentamycin lebih mudah terdegradasi akibat suhu panas dibandingkan dengan sediaan ekstrak buah mengkudu. Fenomena yang luar biasa juga terjadi pada seluruh sampel $\mathrm{KE}+\mathrm{ZAL}$ setelah dilakukan pemanasan yakni terjadi kenaikan zona hambat hingga $84,59 \%$ yang terjadi pada suhu aktivasi zeolit $100^{\circ} \mathrm{C}$ terhadap S.aureus. Dari data tersebut, dapat disimpulkan bawah ZAL mampu meningkatkan unjuk kerja sediaan $\mathrm{KE}+\mathrm{ZAL}{ }_{1000 \mathrm{c}}$ yang bermakna bahwa $\mathrm{ZAL}$ dengan suhu aktivasi $100{ }^{\circ} \mathrm{C}$ paling optimum meningkatkan kestabilan ekstrak buah mengkudu terhadap bakteri S.aureus.

Hal yang berbeda terjadi pada Tabel 2, yakni seluruh sediaan $\mathrm{KE}+\mathrm{ZAL}$ justru mengalami penurunan zona hambat setelah dilakukan pemanasan dengan rata-rata namun rata-rata prosentase penurunan masih lebih kecil dibandingkan penurunan prosentase KP (gentamycin) dan $\operatorname{KE}(16,7 \%$ dan $8,2 \%)$. Hal ini bermakna bahwa ZAL belum mampu mempertahankan kestabilan sediaan ekstrak buah mengkudu terhadap bakteri $P$.aeruginosa. Kejadian ini mungkin disebabkan karena umumnya bakteri gram negatif seperti P.aeruginosa memiliki sistem membran ganda dimana membran plasmanya diselimuti oleh membran luar permeabel dan mempunyai dinding sel tebal berupa peptidoglikan yang terletak di antara membran dalam dan membran luarnya [16]. 
Dari tabel pengamatan juga menunjukkan bahwa baik ekstrak buah mengkudu saja maupun ekstrak buah mengkudu kombinasi zeolit menunjukkan adanya aktivitas antibakteri terhadap S.aureus dan P.aeruginosa. Berdasarkan Tabel 1 dan 2 dapat dilihat bahwa KE memiliki aktivitas antibakteri lebih baik daripada KP terhadap kedua bakteri tersebut sebelum dilakukan pemanasan. Hal ini dilatar belakangi terdapatnya zat aktif dari ekstrak buah mengkudu yang berfungsi sebagai antibakteri antara lain adalah flavonoid, acubin, asperuloside, dan beberapa senyawa antarquinon. Senyawa aktif yang terdapat pada ekstrak tanaman memiliki mekanisme penghambatan dengan cara mengganggu komponen penyusun peptidoglikan pada sel bakteri, sehingga lapisan dinding sel tidak terbentuk secara utuh dan menyebabkan kematian sel tersebut. Mekanisme lainnya yaitu terjadi denaturasi protein sehingga meningkatkan permeabilitas membran sel. Denaturasi protein menyebabkan gangguan dalam pembentukan sel sehingga merubah komposisi komponen protein, fungsi membran sel yang terganggu dapat menyebabkan meningkatnya permeabilitas sel, sehingga mengakibatkan kerusakan sel bakteri.

Tabel 3. Tabel Test Statistik Hasil Uji Kruskal Wallis

\section{Test Statistics ${ }^{\mathrm{a}, \mathrm{b}}$}

Zonahambat bakteriuji

\begin{tabular}{lr|r}
\hline Chi-Square & 20.247 & .000 \\
\hline Df & 6 & 6 \\
\hline Asymp. Sig. & .003 & 1.000 \\
\hline
\end{tabular}

a. Kruskal Wallis Test

b. Grouping Variable: dosis

Dari Tabel 3 test statistik menunjukan nilai Asymp. Sig $(0.003)<$ nilai $p(0.05)$ maka HO ditolak sehingga dapat disimpulkan ada perbedaan signifikan di semua perlakuan. Untuk melihat perlakuan mana saja yang memberikan pengaruh yang signifikan dilanjutkan uji lanjut dengan mann whitney yang disajikan pada Tabel 4 dan 5.

Tabel 4. Hasil Uji Mann Whitney Zona Hambat Terhadap S.aureus Sebelum dan Sesudah Pemanasan

\begin{tabular}{cccr}
\hline Sampel & $\begin{array}{c}\text { Sebelu } \\
\mathbf{m}(\mathbf{m m})\end{array}$ & $\begin{array}{c}\text { Sesudah } \\
(\mathbf{m m})\end{array}$ & $\begin{array}{c}\text { Respon } \\
\text { Hambatan }\end{array}$ \\
\hline KN & $0^{\mathrm{a}}$ & $0^{\mathrm{a}}$ & Tidak ada \\
$\mathrm{KP}$ & $17,4^{\mathrm{b}}$ & $10,61^{\mathrm{b}}$ & Kuat \\
$\mathrm{KE}$ & $20,68^{\mathrm{c}}$ & $15,00^{\mathrm{c}}$ & Kuat \\
$\mathrm{KE}+Z \mathrm{ZL}_{100}$ & $15,97^{\mathrm{d}}$ & $29,48^{\mathrm{d}}$ & Sangat Kuat \\
$\mathrm{KE}+\mathrm{ZAL}_{200}$ & $15,71^{\mathrm{d}}$ & $28,33^{\mathrm{d}}$ & Sangat Kuat \\
$\mathrm{KE}+Z A L 300$ & $18,17^{\mathrm{d}}$ & $26,67^{\mathrm{d}}$ & Sangat Kuat \\
$\mathrm{KE}+Z A L 400$ & $16,98^{\mathrm{d}}$ & $27,54^{\mathrm{d}}$ & Sangat Kuat
\end{tabular}

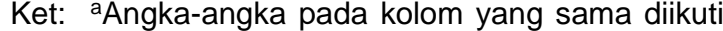
huruf tika atas yang sama (di belakang simpangan baku) tidak berbeda nyata pada taraf uji 5\% (Uji Mann whitney).

Tabel 5. Hasil Uji Mann Whitney Zona Hambat Terhadap P.aeruginosa Sebelum dan Sesudah Pemanasan

\begin{tabular}{cccr}
\hline Sampel & $\begin{array}{c}\text { Sebel } \\
\text { um } \\
(\mathbf{m m})\end{array}$ & $\begin{array}{c}\text { Sesudah } \\
(\mathbf{m m})\end{array}$ & $\begin{array}{c}\text { Respon } \\
\text { Hambatan }\end{array}$ \\
\hline $\mathrm{KN}$ & $0^{\mathrm{a}}$ & $0^{\mathrm{a}}$ & Tidak ada \\
$\mathrm{KP}$ & $12,65^{\mathrm{b}}$ & $10,84^{\mathrm{b}}$ & Kuat \\
$\mathrm{KE}$ & $17,04^{\mathrm{c}}$ & $15,75^{\mathrm{c}}$ & Kuat \\
$\mathrm{KE}+\mathrm{ZL}_{100}$ & $30,89^{\mathrm{d}}$ & $26,54^{\mathrm{d}}$ & Sangat Kuat \\
$\mathrm{KE}+\mathrm{ZL}_{200}$ & $29,26^{\mathrm{d}}$ & $27,29^{\mathrm{d}}$ & Sangat Kuat \\
$\mathrm{KE}+\mathrm{ZL}_{300}$ & $30,25^{\mathrm{d}}$ & $27,56^{\mathrm{d}}$ & Sangat Kuat \\
$\mathrm{KE}+Z A L_{400}$ & $31,39^{\mathrm{d}}$ & $27,33^{\mathrm{d}}$ & Sangat Kuat \\
\end{tabular}

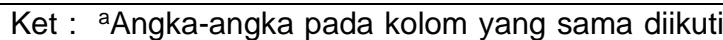
huruf tika atas yang sama (di belakang simpangan baku) tidak berbeda nyata pada taraf uji $5 \%$ (Uji Mann whitney).

Dari hasil uji mann whitney pada Tabel 4 dan 5 menunjukkan bahwa antara KN, KE dan $\mathrm{KE}+\mathrm{ZAL}$ memiliki perbedaan respon hambat yang berbeda. Namun, pada Tabel 3 terjadi perbedaan respon hambat dari kuat menjadi sangat kuat setelah dilakukan pemanasan pada $\mathrm{KE}+\mathrm{ZAL}$ terhadap bakteri S.aureus. Hal ini bermakna bahwa ZAL memiliki unjuk kerja yang baik dalam mempertahankan sediaan ekstrak buah mengkudu, terutama pada suhu aktivasi ZAL $100^{\circ} \mathrm{C}$. 
Hal yang berbeda terjadi pada Tabel 4, yakni pada $\mathrm{KE}+\mathrm{ZAL}$ meskipun terjadi penurunan zona hambat setelah dilakukan pemanasan, namun respon hambatan yang dihasilkan masih sangat kuat dan tidak berbeda secara siginifikan. Dengan demikian, dapat dikatakan bahwa ZAL belum mampu mempertahankan kestabilan sediaan esktrak buah mengkudu dalam menghambat bakteri P.aeruginosa.

\section{KESIMPULAN DAN SARAN}

\section{KESIMPULAN}

Sediaan ekstrak buah mengkudu memberikan zona hambat sebesar 20,68 $\mathrm{mm}$ terhadap $S$. aureus dan $17,04 \mathrm{~mm}$ terhadap $P$. aeruginosa. $\mathrm{Hal}$ ini menuujukkan bahwa ekstrak buah mengkudu mampu memberikan unjuk kerja yang lebih baik dibandingkan dengan kontrol positif salep Gentamycin yang hanya memberikan zona hambat sebesar $17,4 \mathrm{~mm}$ terhadap S.aureus dan $12,65 \mathrm{~mm}$ terhadap $P$. aeruginosa. Sediaan esktrak buah mengkudu yang ditambahkan dengan Zeolit Alam Lampung (ZAL) yang telah diaktivasi pada suhu berbeda juga memberikan unjuk kerja yang baik yakni pada ZAL suhu $300{ }^{\circ} \mathrm{C}$ memberikan zona hambat $18,17 \mathrm{~mm}$ terhadap bakteri $S$. aureus dan ZAL pada suhu $100^{\circ} \mathrm{C}$ memberikan zona hambat $30,89 \mathrm{~mm}$ terhadap $P$. aeroginosa sebelum dilakukan pemanasan. ZAL pada suhu aktivasi 100 ${ }^{\circ} \mathrm{C}$ berpotensi untuk mempertahankan kestabilan sediaan esktrak buah mengkudu setelah dilakukan pemanasan pada suhu $40^{\circ} \mathrm{C}$ (24 jam) dengan prosentase kenaikan zona hambat terbesar $84,6 \%$ milik $\mathrm{KE}+\mathrm{ZeO}_{1000 \mathrm{c}}$ yang jika dibandingkan dengan Kontrol Ekstrak (KE) yang justru menunjukkan penurunan zona hambat sebesar 39,02 \% untuk Staphylococcus aureus. Trend yang berbeda terjadi pada sediaan terhadap Pseudomonas aeruginosa, yakni ZAL tidak mampu mempertahankan kestabilan ekstrak buah mengkudu, karena setelah dilakukan pemanasan pada suhu $40^{\circ} \mathrm{C}(24$ jam) terjadi penurunan zona hambat terbesar pada $\mathrm{KE}+\mathrm{ZeO}_{1000 \mathrm{c}}$ sebesar 14,08 $\%$ dan Kontrol Ekstrak (KE) juga mengalami penuruan zona hambat sebesar $7,57 \%$.

\section{SARAN}

Perlu dilakukan uji daya antibakteri terhadap sampel ZAL saja untuk melihat apakah ZAL memiliki aktivitas antibakteri. Perlu dilakukan uji stabilitas metode freeze thaw dengan penyimpanan sampel pada suhu dingin $\left(4^{\circ} \mathrm{C}\right)$ untuk melihat apakah seluruh sampel memiliki aktivitas antibakteri.

\section{UCAPAN TERIMAKASIH}

Pada kesempatan ini peneliti mengucapkan terimakasih kepada Ristek DIKTI yang telah memberikan hibah melalui Penelitian Dosen Pemula (PDP) Tahun usulan 2017.

\section{DAFTAR PUSTAKA}

[1] Asriani. 2008. Profil Lampung Mencakup Data Penduduk Sumber Daya Alam dan Ekonomi Makro. http//:www.M.News.viva.co.idnews/re ad/3507provinsi_Lampung, September 2014].

[2] Nasikin, M. 1998. Sintesis Etilen dari Etanol dengan Katalis H-Zeolit Alam. Jurnal Teknologi. XII, 296.

[3] Damayanti, S.I., Ginting, S.B., Nur Khasanah, Devi, O.V., Aufa, Y.S. 2015. Pengaruh aktivasi zeolit alam Lampung terhadap adsorben gas $\mathrm{CO}_{2}$ dari Biogas. Seminar Nasional Sains dan Teknologi VI, LPP UNILA.

[4] Slamet, Ellyana M, Bismo, S. 2008. Modifikasi Zeolit Alam Lampung Dengan

Fotokalis TiO2 melalui Metode Sol Gel dan Aplikasinya Untuk Penyisihan Fenol. Jurnal Teknologi Universitas Indonesia. 
[5] Ginting A.B., Anggraini D, Indaryati S, Kriswarini R. 2007. Karakterisasi Komposisi Kimia, Luas Permukaan Pori dan Sifat Termal dari Zeolit Bayah, Tasikmalaya, dan Lampung. J.Tek.Bhn.Nukl. 3(1):148.

[6] Amalia, Fitri. 2012. Formulasi Ekstrak Kulit Buah Delima dan Daun Dewandaru Sebagai Sediaan Antibakteri dan Penggunaan Zeolit Untuk Menjaga Stabilitas Formula. Tesis. Institut Pertanian Bogor.

[7] Choi G.J. 2009. In vitro and In vivo Antibacterial Activity of Punica granatum Peel Ethanol Extract Against Salmonella. eCAM oxfordjournals. Nep 105:1-8.

[8] Peter, J.K. 2014. Antibacterial activity and of seed and leaf extract of Carica (papayavar pusa drawf L.) Journal of Pharmacy and Biological Science. Vol. 9 ; 20-37.

[9] Sahoo, K., Dhal, N.K., Sahoo, S.L., Lenka, S.S. 2012. Comparative Phytochemical and Antimicrobial Study of Morinda Pubescens SM and Morinda citrifolia L. International Journal of Pharmacy and Pharmaceutical Sciences. Vol.4 (3) : 426-429.

[10] Malinggas, F., Pangemanan, D.H.C.,Mariati, N.W. 2015. Uji Daya Hambat Ekstrak Buah Mengkudu Terhadap Pertumbuhan Streptococcus mutans Secara In Vitro. Jurnal IImiah Farmasi-UNSRAT. Vol. 4 (4) ; 22-26.

[11] Puttarak P, Charoonratana T, Panichayupakaranant. 2010. Antimicrobial Activity and Stability of Rhinacanthins-rich Rhinacanthus nasutus Exrtact. Phytomedicine Journal Elsevier. 17:323-327.
[12] Franje C.A. 2010. Differential Heat Stability of Amphenicols Characterirized by Structural Degradation, Mass Spectrometry and Antimicrobial Activity. Journal of Pharmaceutical and Biomedical Analysis 53:869-877.

[13] Sacramento, C.K., Ferreira, L.M., De Franca, L.P. 2014. Evaluation of Antitumoral and antimicrobial activity of Morinda citrifolia L. Grown in Southeast Brazil. Acta Cirurgia Brasileira. Vol. 29(2) : 1014.

[14] Murdiatt, T.B., Adiwinatai, G., Hildasari, D. 2000. Penelusuran Senyawa Aktif dari Buah Mengkudu (Morinda citrifolia L) Dengan Aktivitas Antelmintik Terhadap Haemonchus contortus. Jurnal IImu Ternak dan Veteriner. Vol. 5 (4) : 255-259.

[15] Cooper GM., Hausman RE. 2007. The Cell : A Molecular Approach . 4th ed. Sunderland : Sinauer Associates, Inc.

[16] Irnawati, D., Agustiono, P., Wardhani, E.H. 2010. Pengaruh Konsentarsi $\mathrm{Cu}$ dalam Cu-Zeolite Terhadap Daya Antibakteri Pada Streptococcus Mutans. Jurnal Zeolit Indonesia. Vol. 9 (2) : 47-53.

[17] Sunarintyas, S., Harsini, Widyastuti, N.H., Inan, C.W. 2006. Pengaruh Aktivasi Panas dan Penambahan $\mathrm{Cu}$ Pada Zeolit Terhadap Daya Antimikroba Pada Staphylococcus aureus. IJD, edisi khusus KPPIG XIV. 